\title{
บusisersaly
}

\section{EMBEDDING EMPLOYABILITY IN THE CURRICULUM - THE AWARE FRAMEWORK}

\begin{abstract}
Ayre, N., McChesney, I., \& Sterritt, R. (2016). EMBEDDING EMPLOYABILITY IN THE CURRICULUM - THE AWARE FRAMEWORK. In Unknown Host Publication (pp. 2596-2598). International Academy of Technology, Education and Development. http://library.iated.org/view/AYRE2016EMB
\end{abstract}

Link to publication record in Ulster University Research Portal

\section{Published in:}

Unknown Host Publication

Publication Status:

Published (in print/issue): 01/03/2016

\section{Document Version \\ Author Accepted version}

\section{General rights}

Copyright for the publications made accessible via Ulster University's Research Portal is retained by the author(s) and / or other copyright owners and it is a condition of accessing these publications that users recognise and abide by the legal requirements associated with these rights.

\section{Take down policy}

The Research Portal is Ulster University's institutional repository that provides access to Ulster's research outputs. Every effort has been made to ensure that content in the Research Portal does not infringe any person's rights, or applicable UK laws. If you discover content in the Research Portal that you believe breaches copyright or violates any law, please contact pure-support@ulster.ac.uk. 


\title{
EMBEDDING EMPLOYABILITY IN THE CURRICULUM - THE AWARE FRAMEWORK
}

\author{
Nicola Ayre, lan McChesney and Roy Sterritt
}

Ulster University, UK

\begin{abstract}
An integral aspect of Ulster University's learning and teaching strategy is "to enhance Ulster's role as a sector leader for student employability as an integral part of the wider student experience." The Computing Subject Area underwent a highly successful Revalidation in 2012/13. As part of our revalidation activity we were keen to develop an enhanced employability strand, underpinned by a greater awareness and understanding of professional issues within the curriculum.

Through structured engagement with the University employability unit and curriculum support teams and through work conducted by a working group of the course committee, a progressive approach to employability was devised and introduced in September 2013 - the AWARE Framework.
\end{abstract}

Keywords: Employability, Curriculum.

\section{INTRODUCTION}

A session during a School away day in 2011 was led by members of the Viewpoints team - a central university unit for facilitating curriculum review and enhancement. One outcome was an initial draft of the AWARE framework:

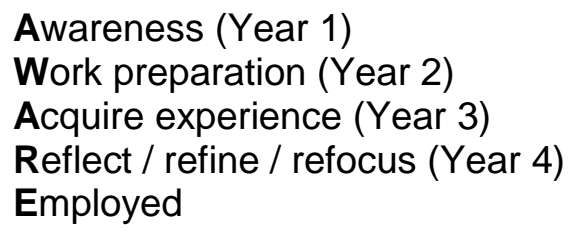

Awareness (Year 1) Work preparation (Year 2)

Acquire experience (Year 3)

Reflect / refine / refocus (Year 4)

Employed

AWARE helped formalise our existing employability coverage. It is implemented through an 'anchor' module in each of Years 1 - 4, with employability skills taught, developed and assessed elsewhere as appropriate, including CPD (continuing professional development) modules.

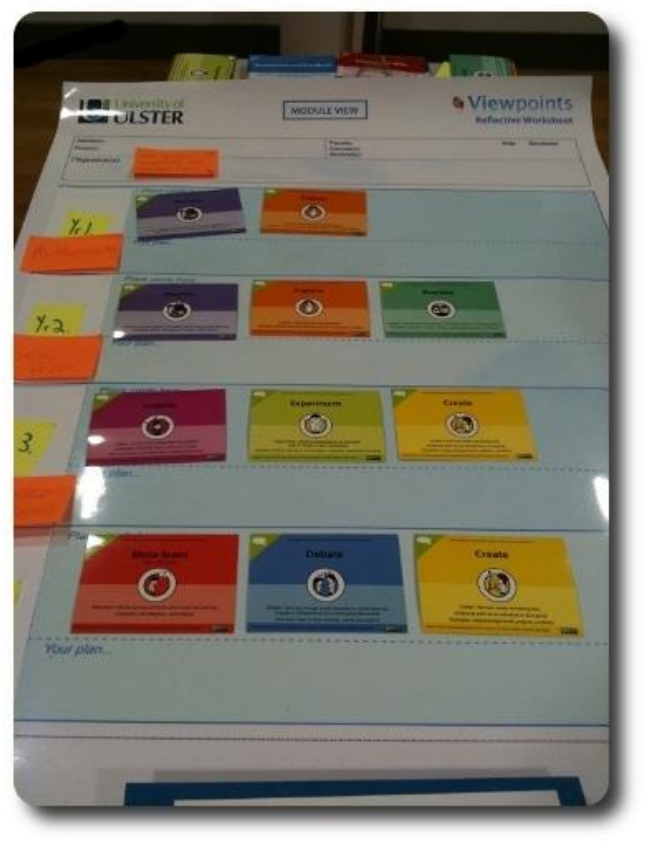

This progressive approach to employability is consistent with that recommended by the HEFCE (Higher Education Funding Council for England) Enhancing Student Employability Co-Ordination Team (ESECT) and which underpins their description of employability as "a set of achievements skills, understanding and personal attributes - that makes graduates more likely to gain employment and be successful in their chosen occupations, which benefits themselves, the workforce, the community and the economy." (Yorke, 2006).

Existing coverage of employability has had some very positive outcomes. For example, a placement employer recently commented about a student, "his attitude to his work is meticulous, and his career attitude is always 'how can I do better' or 'give me some advice!'." Through AWARE we aspire for all of our students to receive this response. 


\section{THE FRAMEWORK EXPLAINED}

\subsection{Awareness (Year 1)}

Year 1 is about raising awareness of the role and importance of employability skills.

Year 1
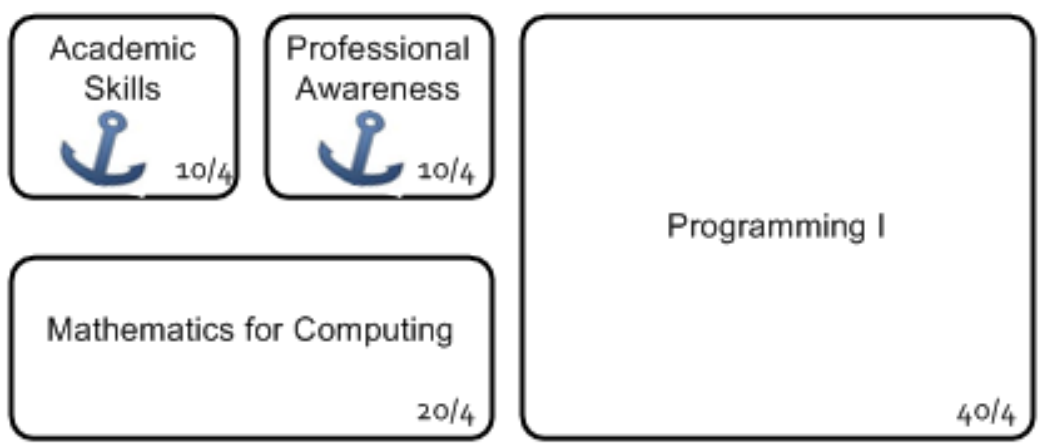

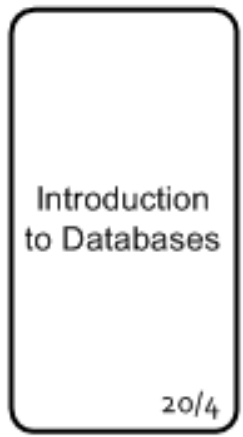

Professional Awareness is the anchor module for initial development. With Academic Skills for Computing and other level 4 modules, Year 1 addresses, inter alia:

- Employer expectations.

- Role of Year 1 and Year 2 marks in securing early placement interviews.

- Returning students meeting with new intake.

- Careers talks and guest lectures.

- Initial introduction to CVs, and skills acquired to date, via PACE (University's "Professional and Career Enhancement" system).

- Presentation skills.

Awareness is also developed by the use of CPD modules for example: PPD105 "Building your Skills". 


\subsection{Work preparation (Year 2)}

In Year 2 the focus is on work preparation and engaging with the placement preparation process.

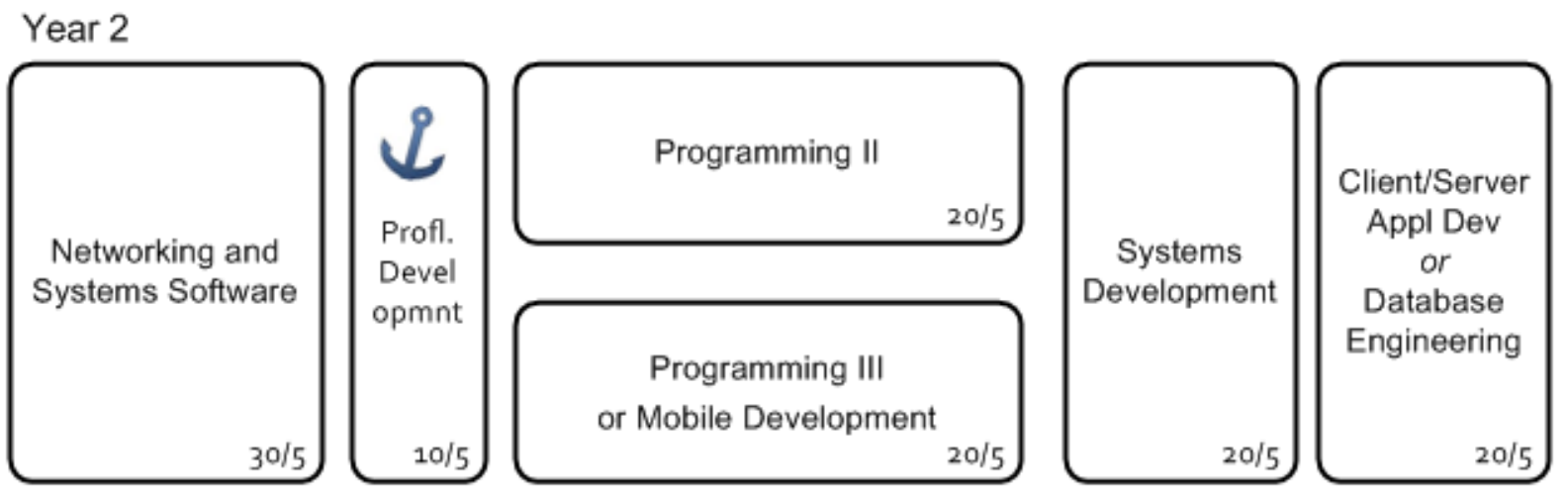

$\mathcal{L}$ With Professional Development as the anchor module, Year 2 considers:

- Ongoing development of Year 1 professional development activities.

- Technical competence for professional practice.

- Ongoing CV development.

- Employability skills development and practice.

One student noted, "I was invited for my first Placement interview in Semester 1. My CV got me through the door, step two was making a presentation to 15 people; it was nerve-racking, but the experience developed in Year 1 really helped."

Work Preparation is further enhanced by the use of CPD modules for example: PPD184 "Work Experience Skills Builder".

Foundation Degree students (who enter the course directly in year 2) are encouraged to reflect on how their worked-based learning module has prepared them for seeking graduate employment.

\subsection{Acquire experience (Year 3)}

Year 3 professional practice is a mandatory requirement of the course and is fundamental to the development of employability skills for the student. This is the primary opportunity for all students to acquire experience and knowledge.

Professional practice often influences Year 4 module choice, project choice and future career pathway. 


\subsection{Reflect / refine / refocus (Year 4)}

Having reflected on their placement experience, Year 4 is the opportunity for students to refine their skills and refocus on their career direction.

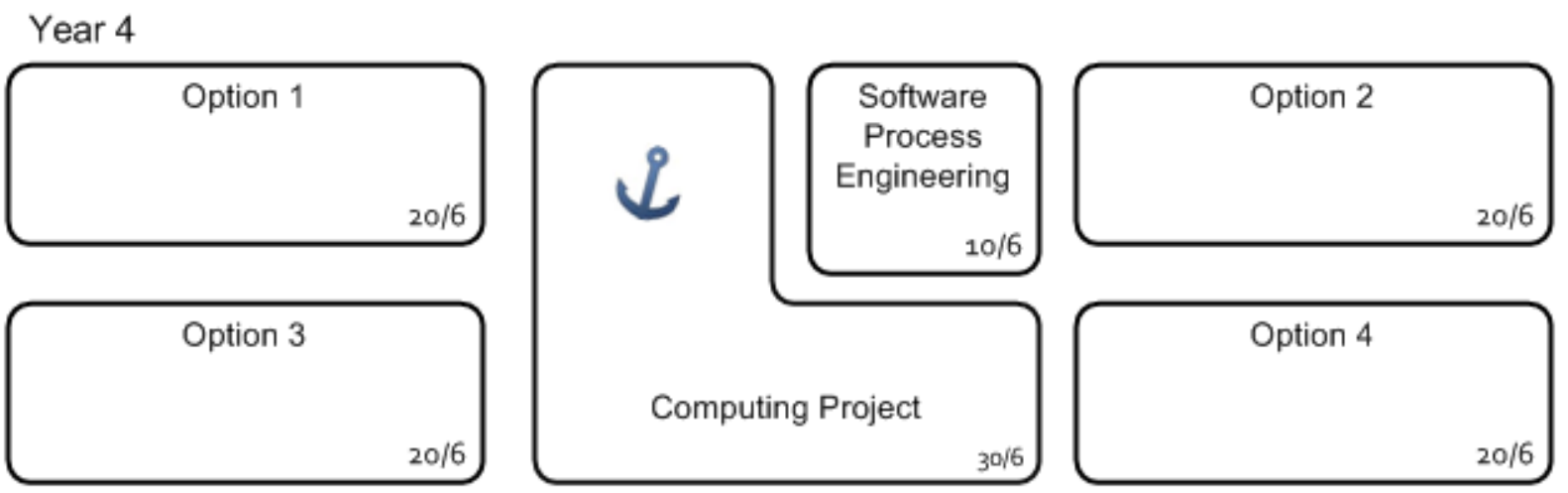

The final year Project module is an important aspect of this. Students may choose a project derived from, or building upon, their placement experience. The Project provides a context to:

- Assess what employability skills have been learned throughout the programme so far.

- Allow the student to reflect on why they are doing a project and its employability benefits. For example: showcasing their strengths, time management and presentation skills.

Further reflection, refinement and refocusing is encouraged by the use of CPD modules for example: PPD102 "Graduation - What Next?".

\subsection{Employed}

As part of the Year 4 reflective activity each student prepares a Project Showcase - an assessed reflective report which allows the student to explore their project work from an employability perspective. One student noted, "the Project Showcase made me think about my project as something I could use at interviews." Another said, "the project showcase was something I could talk confidently about at my interview, l've just secured my dream job, it really helped."

\section{CONCLUSION}

The University Revalidation Panel, in their formal feedback, regarded AWARE and our enhanced employability strand as exemplary. Its true value however, is in facilitating a growing body of students to become more self-AWARE of the skills they have developed and learn to review their progress against targets they have set.

\section{REFERENCES}

[1] Yorke, M., 2006. Employability in higher education: what it is, what it is not. The Higher Education Academy. 